\title{
Pengembangan Karakter Peserta Didik Berbasis Pendidikan Agama Islam

\author{
(Penelitian di SMA Ksatria Nusantara Boarding School \\ Kecamatan Padaherang Kabupaten Pangandaran)
}

\author{
Ita Thoyyibah \\ Institut Agama Islam Darussalam (IAID) Ciamis \\ Email: ita_thoyyibah94@yahoo.co.id \\ Iwan Setiawan \\ Institut Agama Islam Darussalam (IAID) Ciamis \\ Email: iwenk09@yahoo.com \\ Received: February 24, 2018 | Accepted: September 28, 2018
}

\begin{abstract}
This research assumes that religious teachings can be the foundation and foundation for character education. This research can prove the truth of this assumption. This research assumes that religious teachings can be the foundation and foundation for character education. This study tries to prove the truth of these assumptions. The study uses descriptive analysis method. Data obtained by interview, observation, study of school documents. Interviews were conducted with a number of informants, ranging from students, teachers, students' parents, and the community around the school. The results of this study confirm that religious education can be a source for character education. The values of patience, honesty, discipline, responsibility, respect, respect, courtesy, and love to read are the main character values in the Islamic religion.
\end{abstract}

\begin{abstract}
Abstrak
Penelitian ini berasumsi bahwa ajaran agama dapat menjadi fondasi dan dasar bagi pendidikan karakter. Penelitian ini berusaha membuktikan kebenaran asumsi tersebut. Penelitian menggunakan metode deskriptif analisis. Data-data diperoleh dengan wawancara, pengamatan, kajian terhadap dokumen sekolah. Wawancara dilakukan terhadap sejumlah informan, mulai dari siswa, guru, orang tua siswa, serta masyarakat sekitar sekolah. Hasil penelitian ini menegaskan bahwa pendidikan agama dapat menjadi sumber bagi pendidikan karakter. Nilainilai kesabaran, kejujuran, disiplin, tanggung jawab, hormat-menghormati, sopan santun dan gemar membaca adalah nilai-nilai karakter utama dalam agama Islam.
\end{abstract}




\section{Keywords}

Islamic education, integrated curriculum, partial curriculum

\section{Pendahuluan}

Manusia dibekali dua potensi dasar untuk menjadi baik atau buruk. Pengaktualisasian baik atau buruk yang dilakukan manusia tergantung keputusan atau pilihan yang diambilnya. Semua tergantung seberapa besar seseorang dibentuk sejak dini untuk menggunakan akal sehatnya dalam mengambil keputusan. Semua tentu tidak lepas dari pendidikan yang diperolehnya (Helmawati, 2017, p. 1).

Pengertian pendidikan secara umum adalah proses pengubahan sikap dan tata laku seseorang atau kelompok orang dalam usaha mendewasakan manusia melalui upaya pengajaran dan pelatihan (Ma'shumah, 2001, p. 214). Lebih lanjut Saondi dan Suherman memaparkan bahwa pendidikan pada hakikatnya adalah usaha membudayakan atau memanusiakan manusia. Pendidikan sangat strategis untuk mencerdaskan kehidupan bangsa dan diperlukan guna meningkatkan mutu bangsa secara menyeluruh (Saondi \& Suherman, 2015, p. 1). Pendidikan adalah usaha sadar dan terencana untuk mewujudkan suasana belajar dan proses pembelajaran agar peserta didik secara aktif mengembangkan potensi dirinya untuk memiliki kekuatan spiritual keagamaan, pengendalian diri, kepribadian, kecerdasan, akhlak mulia, serta keterampilan yang diperlukan dirinya, masyarakat, bangsa dan negara.

Pendidikan tidak hanya terkait dengan bertambahnya ilmu pengetahuan, namun harus mencakup aspek sikap dan perilaku, sehingga dapat menjadikan anak sebagai manusia yang bertakwa, berilmu dan berakhlak mulia (Sani, 2016, p. 6). Upaya mendidik anak-anak menjadi pribadi yang baik perlu diwujudkan bersama sebagai prioritas dalam hubungan kerjasama antara keluarga, masyarakat, maupun pemerintah, khususnya melalui bidang pendidikan. Hal ini diperkuat oleh pandangan Helmawati, bahwa fokus pendidikan adalah pembentukan karakter pada manusia (Helmawati, 2017, p. iv). Berhasilnya seseorang menjadi manusia yang manusiawi akan sangat tergantung pada karakternya, bahkan maju mundurnya suatu negara pun tergantung karakter manusianya.

Individu yang berkarakter baik atau unggul adalah seseorang yang berusaha melakukan hal-hal yang terbaik terhadap Tuhan Yang Maha Esa, dirinya, sesama, lingkungan, bangsa dan negara pada umumnya, yaitu dengan mengoptimalkan potensi (pengetahuan) dirinya dan disertai dengan kesadaran, 
emosi dan motivasinya (Aqila \& Sujak, 2011, p. 3). Karakter dapat dimaknai sebagai nilai dasar yang membangun pribadi seseorang terbentuk, baik karena pengaruh hereditas maupun pengaruh lingkungan. Karakter tersebutlah yang membedakan seseorang dengan orang lain, serta diwujudkan dalam sikap dan perilakunya dalam kehidupan sehari-hari. Dengan demikian, banyaknya masalah yang diakibatkan oleh kurangnya pembentukan karakter disebabkan karena tidak adanya penanaman nilai-nilai akhlak, moral dan budi pekerti pada anak, sehingga anak akan bertindak semaunya sendiri tanpa memikirkan dampak akibat perbuatannya.

Dalam perspektif Islam, secara teoritik sebenarnya pendidikan karakter telah ada sejak Islam diturunkan di dunia seiring diutusnya Nabi Muhammad saw. untuk memperbaiki atau menyempurnakan akhlak manusia. Rasululloh saw. bersabda:

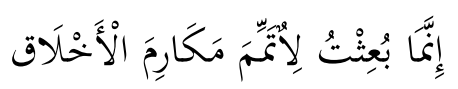

Sesungguhnya aku diutus untuk menyempurnakan akhlak-akhlak mulia [H.R. Malik, Hakim dan Baihaqi]

Istilah akhlak yang dimaksudkan dalam hadits tersebut sejajar dengan pemaknaan karakter. Oleh karena misinya sebagai pengemban perbaikan akhlak, maka beliau senantiasa menunjukkan uswah hasanah (suri tauladan yang baik), yakni sebagai bentuk internalisasi nilai dan prototype akhlak yang baik agar umatnya dapat menirunya secara mudah (Mujib \& Mudzakkir, 2006, p. xv). Tentunya, pendidikan karakter bukan sekedar mengajarkan mana yang benar dan mana yang salah. Lebih dari itu, pendidikan karakter menanamakan kebiasaan tentang hal mana yang baik, sehingga peserta didik menjadi paham tentang mana yang benar dan salah, mampu merasakan nilai yang baik dan biasa melakukannya (Aqib \& Amrullah, 2017, p. 14).

Dari beberapa pernyataan di atas menjadi jelas bahwa karakter dibentuk melalui proses Pendidikan. Sementara itu, agama Islam sendiri adalah salah satu ajaran yang berisi tentang bagaimana agar manusia memiliki akhlak mulia. Dengan demikian, fokus mendidik anak agar memiliki akhlak mulia diaktualisasikan dengan membiasakan, memberikan dan memahamkan, serta menumbuhkan kemampuan beragama yang benar (Helmawati, 2017, p. 2). Hal ini diperkuat oleh pandangan Tolchah, bahwa Pendidikan Agama Islam (PAI) adalah usaha sadar dan terencana dalam menyiapkan peserta didik untuk mengenal, memahami, hingga mengimani, bertakwa dan berakhlak mulia dalam mengamalkan ajaran Islam dari sumber utamanya Alquran dan Hadis, melalui kegiatan bimbingan, pengajaran, latihan, serta penggunaan pengalaman (Tolchah, 2015, p. 64). 
Penerapan penggunaan agama Islam diharapkan tidak hanya dapat meningkatkan keberhasilan dalam proses belajar mengajar, namun seorang guru dituntut untuk mengembangkan segala potensi siswa sebagai peserta didik, terutama dalam membentuk dan membina karakternya. Proses belajar mengajar Pendidikan Agama Islam dengan penekanan karakter dapat bermakna dan berdaya guna dalam menciptakan hasil-hasil yang dicapai oleh siswa sebagai peserta didik, serta memberikan membentuk watak dan kepribadian siswa tersebut.

Berdasarkan pendapat yang dikemukakan di atas, maka pendidikan karakter merupakan salah satu bagian pendidikan Islam yang sangat dipelukan. Karakter yang baik dari seorang anak akan melahirkan generasi yang baik pula, yaitu generasi muda yang taat kepada Allah Swt., berbakti kepada orang tua dan memperhatikan hak-hak bagi saudara muslim lainnya.

SMA Ksatria Nusantara merupakan salah satu sekolah berbasis pesantren. Hal tersebut sangat jelas sebagaimana terlihat dalam visi misinya, yaitu sekolah yang membentuk kader pemimpin bangsa yang berkualitas dan berkarakter yang berwawasan kebangsaan, kejuangan dan bercirikan kenusantaraan dipadukan dengan pendidikan pesantren, serta memiliki daya saing nasional. Dari penjelasan di atas, dapat ditangkap bahwa pengembangan karakter secara nyata telah diaplikasikan dalam program-program sekolah. Di sisi lain, kultur sekolah berasrama yang dikembangkan oleh SMA Ksatria Nusantara memberikan dampak positif tersendiri. Oleh karena itu, menarik untuk dikaji lebih lanjut mengingat proses pendidikan yang ada di boarding school, khususnya di SMA Ksatria Nusantara yang memiliki watak berbeda dengan sekolah pada umumnya. Sekolah berasrama tersebut terlihat memiliki basis pembentukan karakter yang terlihat lebih kental dengan intensitas pendidikan nilai yang kuat, serta berbagai macam kegiatan penunjang lainnya yang dilakukan di pesantren.

Latar belakan yang telah dikemukakan di atas membuat penulis tertarik untuk melakukan penelitian dengan judul: "Pengembangan Karakter Peserta Didik Berbasis Pendidikan Agama Islam (Penelitian di SMA Ksatria Nusantara Boarding School Kecamatan Padaherang Kabupaten Pangandaran)."

\section{Kajian Teori}

Karakter berasal dari bahasa Yunani "kharakter" yang berakar dari diksi "kharassein" yang berarti melihat atau mengukir (to inscribelto engrave). Sedangkan dalam bahasa latin, istilah karakter bermakna membedakan tanda. Dalam bahasa Indonesia, karakter dapat diartikan sebagai sifat-sifat kejiwaan/tabiat/watak (Narwati, 2013, p. 2). 
Menurut Idi, karakter merupakan kumpulan dari beragam aspek kepribadian yang melambangkan kepribadian seseorang (Idi, 2015, p. 124). Karakter merupakan ciri-ciri tertentu yang sudah menyatu pada diri seorang yang ditampilkan dalam bentuk perilaku. Dengan demikian, karakter merupakan kualitas moral dan mental yang pembentukannya dipengaruhi oleh faktor bawaan (fitrah atau nature) dan lingkungan (sosialisasi atau lingkungan). Potensi karakter yang baik dimiliki seorang sebelum dilahirkan harus terus menerus dibentuk dan dikembangkan melalui sosialisasi dan pendidikan.

Menurut Hermawan, sebagaimana dikutip Furqon Hidayatulloh, bahwa karakter adalah ciri khas yang dimiliki oleh sesuatu benda atau individu (Hidayatulloh, 2009, p. 13). Ciri khas tersebut adalah watak asli dan mengakar pada kepribadian benda atau individu tersebut dan merupakan mesin yang mendorong bagaimana seorang bertindak, bersikap, berujar dan merespon sesuatu. Karakter memungkinkan individu untuk mencapai pertumbuhan yang berkesinambungan, karena karakter memberikan konsistensi, integritas dan energi. Seseorang dapat dikatakan berkarakter jika telah berhasil menyerap nilai dan keyakinan yang dikehendaki masyarakat serta digunakan sebagai kekuatan moral dalam hidupnya. Demikian juga seorang pendidik dikatakan berkarakter jika memiliki nilai dan keyakinan yang dilandasi hakikat dan tujuan pendidikan serta digunakan sebagai kekuatan moral dalam menjalankan tugasnya sebagai pendidik (Hidayatulloh, 2009, p. 13).

Dari beberapa pengertian di atas maka dapat dinyatakan bahwa karakter adalah ciri khas tertentu yang dimiliki oleh individu yang ditampilkan dengan perilaku. Ciri khas tersebut asli dan sudah mengakar yang dapat menjadi pendorong dan penggerak, serta yang membedakan dengan individu lainnya. Seseorang dapat dikatakan berkarakter jika telah berhasil menyerap nilai dan keyakinan yang dikehendaki masyarakat serta digunakan sebagai kekuatan moral dalam dirinya.

Perencanaan menjadi pegangan setiap pemimpin dan pelaksana untuk dilaksanakan. Dengan demikian, melalui perencanaan dapat dipersatukan kesamaan pandangan, sikap dan tindak dalam pelaksanaan di lapangan. Perencanaan merupakan suatu proses yang tidak berakhir bila rencana tersebut telah ditetapkan, rencana yang harus diimplementasikan. Setiap saat selama proses implementasi dan pengawasan, rencana-rencana mungkin memerlukan modifikasi agar tetap berguna. Oleh karena itu perencanaan harus mempertimbangkan kebutuhan fleksibilitas, agar mampu menyesuaikan diri dengan situasi dan kondisi baru secepat mungkin (Al-Hamdani, 2017, p. 69).

Perencanaan pengembangan karakter harus didasarkan pada visi misi pendidikan karakter yang ditetapkan oleh sekolah, yang merupakan cita-cita yang akan diarahkan melalui kinerja lembaga pendidikan (Mushlih, 2018, p. 
160). Tanpa visi yang diungkapkan melalui pernyataan yang jelas dan dapat dipahami oleh semua pihak yang terlibat di dalam lembaga pendidikan tersebut, setiap usaha pengembangan pendidikan karakter akan sia-sia. Oleh karena itu, setiap sekolah semestinya menentukan visi pendidikan yang akan menjadi dasar acuan bagi setiap kerja, pembuatan program dan pendekatan pendidikan karakter yang dilakukan di dalam sekolah.

Menurut Derli Fahlevi, karakter dimulai dari pola pikir yang kemudian diwujudkan dalam tindakan, bila dilakukan terus menerus maka akan menjadi kebiasaan. Karakter yang positif tidak akan muncul dengan sendirinya. Untuk dapat membentuknya, hal pertama yang harus dilakukan adalah mengubah pola pikir, tingkah laku, dan kebiasaan menjadi positif (Fahlevi, 2016, p. 44).

Pengembangan karakter dalam suatu sistem pendidikan adalah keterkaitan antara nilai-nilai perilaku yang dapat dilakukan atau bertindak secara bertahap dan saling berhubungan antara pengetahuan nilai-nilai perilaku dengan sikap atau emosi yang kuat untuk melaksanakannya, baik terhadap Tuhan YME., dirinya, sesama, lingkungan, bangsa dan negara, serta dunia internasional (Gunawan, 2012, p. 39). Perspektif ini sependapat dengan Izzan dan Saehudin yang mengatakan bahwa lingkungan tempat peserta didik hidup diyakini besar pengaruhnya terhadap pembentukan karakter. Faktor lingkungan tersebut meliputi lingkungan keluarga, sekolah, dalam masyarakat luas. Keluarga merupakan lingkungan yang pertama dan utama dialami seorang peserta didik. Situasi keluarga akan turut menentukan bagaimana karakter dibentuk. Sedangkan sekolah merupakan lingkungan tempat bertemu dengan teman-teman yang lain. Pertemuan yang datang dari berbagai budaya dan sosial yang berbeda-beda (Izzan \& Saehudin, 2015, p. 93).

Pembentukan karakter peserta didik tentunya membutuhkan suatu metodologi yang efektif, aplikatif dan produktif agar tujuan yang diharapkan dapat tercapai dengan baik. Menurut Helmawati, metodologi dalam membentuk karakter peserta didik mencakup, pertama dengan sedikit mengajarkan atau berteori. Untuk membentuk seseorang memiliki karakter yang baik minimal perlu contoh dan pembiasaan. Dengan demikian, jika pendidikan karakter ingin berhasil tentu pendidik harus melakukan sedikit pengajaran (sedikit teori) dan memperbanyak praktik. Walaupun jam pelajaran ditambah, jika para pendidik masih menggunakan metode ceramah dan banyak pengajaran, maka karakter lulusan akan tetap sama (Helmawati, 2017, pp. 24-25)

Kedua, dengan peneladanan. Keteladanan dalam pendidikan merupakan metode yang paling berpengaruh bagi anak. Anak pertama kali melihat, mendengar dan bersosialisasi dengan orang tuanya. Hal ini berarti bahwa ucapan dan perbuatan orang tua akan dicontoh anak-anaknya. Demikian pula, 
dengan para pendidik pendamping lainnya, seperti guru dan tokoh masyarakat atau publik figur. Guru, orang tua dan tokoh masyarakat harus terlebih dahulu memiliki karakter yang diajarkan, karena apa yang akan dicontohkan akan ditirunya (Helmawati, 2017, pp. 26-27).

Ketiga, dengan memperbanyak pembiasaan atau praktik. Pembiasaan merupakan suatu keadaan dimana seseorang mengaplikasikan perilaku-perilaku yang belum pernah atau jarang dilaksanakan menjadi sering dilaksanakan, hingga pada akhirnya menjadi kebiasaan. Kebiasaan yang baik yang dicontohkan orang tua pada prosesnya akan menjadi kebiasaan yang baik pula bagi anak-anaknya. Sebaliknya, kebiasaan buruk yang dilakukan orang tua akan menjadi kebiasaan buruk pula bagi anak-anaknya. Dengan demikian, semakin banyak pembiasaan, maka semakin terbentuklah karakter seseorang (Helmawati, 2017, pp. 27-29).

Keempat, dengan motivasi. Motivasi memberikan dampak yang sangat baik dan positif bagi perkembangan kejiwaan manusia, terutama perkembangan pendidikan anak. Motivasi jika diarahkan kepada hal baik maka akan membentuk seorang individu memiliki karakter yang baik. Semakin banyak motivasi yang diberikan, maka semakin tinggi daya juang anak untuk berubah menjadi individu yang lebih baik. Semakin banyak motivasi diberikan, maka semakin besar peluang anak menjadi individu yang berkarakter tangguh (Helmawati, 2017, pp. 29-30).

Keempat, dengan pengawasan dan penegakan aturan yang konsisten. Seseorang yang merasa diawasi akan selalu berusaha menjadi orang yang baik dan benar. Pengawasan dari para pendidik akan menjadi suatu kendali eksternal agar anak didik tetap berperilaku baik dan benar. Jika terjadi penyelewengan atau berubahnya jalur kepada hal-hal yang menyimpang, maka perlu diarahkan, dibimbing, hingga diberi sanksi (Helmawati, 2017, p. 30).

\section{Pelaksanaan Pengembangan Karakter}

Pelaksanaan adalah aktifitas atau usaha-usaha yang dilaksanakan untuk merealisasikan semua rencana dan kebijaksanaan yang telah dirumuskan dan ditetapkan dengan dilengkapi segala kebutuhan, alat-alat yang diperlukan, siapa yang melaksanakan, dimana tempat pelaksanaannya mulai dan bagaimana cara yang harus dilaksanakan (Al-Qarni, 2018).

Pembiasaan merupakan salah satu metode pendidikan Islam yang sangat penting bagi peserta didik, karena dengan pembiasaan inilah akhirnya suatu aktifitas akan menjadi milik pesrta didik di kemudian hari (Djamarah \& Zain, 2002, pp. 71-72). Ciri khas metode pembiasaan adalah kegiatan yang berupa pengulangan berkali-kali dari suatu yang sama. Pengulangan ini sengaja dilakukan berkali-kali supaya asosiasi antara stimulus dan respon menjadi sangat kuat atau tidak mudah dilupakan. Dengan demikian, terbentuklah 
pengetahuan siap atau keterampilan siap yang setiap saat siap untuk dipergunakan oleh yang bersangkutan. Oleh karena itu, sebagai awal dalam proses pendidikan, pembiasaan menjadi cara yang sangat efektif dalam menanam nilai-nilai moral ke dalam jiwa peserta didik. Nilai-nilai yang tertanam dalam dirinya ini kemudian akan termanifestasikan dalam kehidupannya semenjak peserta didik mulai melangkah ke usia dewasa (Arief, 2002, p. 110).

Dalam memantapkan kepribadian peserta didik guna mewujudkan ketahanan sekolah sebagai lingkungan pendidikan dan menyiapkan peserta didik agar berakhlak mulia, demokratis dan menghormati hak-hak sesuai tujuan pendidikan nasional, maka kegiatan pembelajaran mulai dari tahapan kegiatan pendahuluan, inti dan penutup, dipilih dan dilaksanakan agar peserta didik mempraktekan nilai-nilai karakter yang ditargetkan. Selain itu, perilaku guru sepanjang proses pembelajaran harus merupakan model pelaksanaan nilainilai bagi peserta didik (Syarif, Hamzah, \& Mustofik, 2016, pp. 27-28). Keteladanan dalam Pendidikan, pendekatan atau metode yang sangat berpengaruh dan terbukti paling berhasil dalam mempersiapkan dan membentuk dan mengembangkan potensi peserta didik. Keteladanan bukan hanya sekedar memberikan contoh dalam melakukan sesuatu, tetapi juga menyangkut berbagai hal yang dapat diteladani, termasuk kebiasaan-kebiasaan yang baik merupakan contoh bentuk keteladanan (Hidayatulloh, 2009, pp. 105-106).

\section{Hasil Pengembangan Karakter}

Karakter peserta didik yang diharapkan mengarah pada peserta didik yang memiliki karakter mulia memiliki pengetahuan tentang potensi dirinya, yang ditandai dengan nilai-nilai seperti reflektif, percaya diri, rasional, logis, kritis, analitis, kreatif dan inovatif, mandiri, hidup sehat, bertanggung jawab, cinta ilmu, sabar, berhati-hati, rela berkorban, pemberani, dapat dipercaya, jujur, menepati janji, adil, rendah hati, rela berkorban, malu berbuat salah, pemaaf, berhati lembut, setia, bekerja keras, kuat dan lain-lain. Di samping itu, individu juga memiliki kesadaran untuk berbuat yang terbaik atau unggul dan mampu bertindak sesuai potensi dan kesadarannya tersebut. Peserta didik yang berkarakter baik selalu berusaha melakukan hal-hal yang terbaik terhadap Tuhan, dirinya, sesama, lingkungan, bangsa dan negara serta dunia internasional pada umumnya dengan mengoptimalkan potensi (pengetahuan) dirinya dan disertai dengan kesadaran, emosi dan motivasinya (Suyitno, 2012, p. 3).

Pengembangan karakter tentu tidak bisa memberikan sistem evaluasi yang berbentuk pilihan ganda atau menjawab pertanyaan yang sifatnya hafalan, seperti mata pelajaran lain. Lickona, sebagaimana dikutip Kholiq, memaparkan 
hal-hal yang perlu diamati untuk mengetahui hasil dari pengembangan karakter, yaitu: 1) kemajuan karakter peserta didik dapat diamati lewat perilakunya di lingkungan sekolah; 2) efek karakter pada lingkungan luar sekolah; 3) kehidupan peserta didik setelah lulus dari sekolah. (Kholiq, 2012).

Aa Gym mengemukakan bahwa karakter terdiri dari empat hal. Pertama, karakter lemah; misalnya penakut, tidak berani mengambil resiko, pemalas, cepat kalah, belum apa-apa sudah menyerah, dan sebagainya. Kedua, karakter kuat; contohnya tangguh, ulet, mempunyai daya juang yang tinggi, atau pantang menyerah. Ketiga, karakter jelek; misalnya licik, egois, serakah, sombong, pamer, dan sebagainya. Keempat, karakter baik; seperti jujur, terpercaya, rendah hati, dan sebagainya (Hidayatulloh, 2009, p. 10).

\section{Metode Penelitian}

Metode penelitian yang digunakan dalam penelitian ini adalah metode penelitian deskriptif, yaitu penelitian yang dimaksudkan untuk menyelidiki keadaan, kondisi atau hal-hal lain yang sudah disebutkan, yang hasilnya dipaparkan dalam bentuk laporan penelitian (Arikunto, 2002, p. 3). Tujuan metode penelitian deskriptif adalah untuk melukiskan secara sistematis fakta atau karakteristik populasi tertentu atau bidang tertentu secara faktual dan cermat (LPP, 2014, p. 23).

Karakter penelitian ini merupakan penelitian kualitatif, yaitu penelitian yang berusaha mendeskripsikan suatu persoalan dalam bentuk kata-kata dan bahasa mengenai apa yang dialami oleh subjek penelitian misalnya perilaku, persepsi dan tindakan dalam konteks alamiah dengan metode alamiah (Moleong, 2017, p. 6). Penelitian ini mendeskripsikan pengembangan karakter peserta didik berbasis pendidikan agama Islam di SMA Ksatria Nusantara Boarding School Padaherang. Penelitian ini mencakup mekanisme perencanaan, pelaksanaan dan hasil pengembangan karakter peserta didik berbasis pendidikan agama Islam di SMA Ksatria Nusantara Boarding School Padaherang.

Untuk mempermudah dalam pengumpulan data, maka penulis membagi sumber data dalam dua bagian, yaitu: sumber data primer dan sumber data sekunder. Pertama, sumber data primer merupakan bahan atau rujukan utama dalam mengadakan suatu penelitian untuk mengungkapkan dan menganalisa penelitian tersebut. Dalam penelitian kualitatif kata-kata dan tindakan orangorang yang diamati atau diwawancarai merupakan sumber data utama (Moleong, 2017, p. 157). Dalam penelitian di SMA Ksatria Nusantara, sumber data utama berkaitan dengan orang, yaitu: kepala sekolah, waka kurikulum, guru Pendidikan Agama Islam, guru prakarya, guru bahasa sunda dan siswa. 
Kedua, sumber data sekunder adalah data yang dikumpulkan peneliti dari sumber yang telah ada, seperti buku, sumber dari arsip, dokumen pribadi dan dokumen resmi (Moleong, 2017, p. 159). Data sekunder digunakan untuk menunjang penelaahan data-data yang dihimpun dan sebagai pembanding dari sumber data primer. Dalam penelitian di SMA Ksatria Nusantara Boarding School Padaherang, sumber data sekunder dalam penelitian ini diantaranya adalah dokumen/arsip-arsip, seperti sejarah berdirinya SMA Ksatria Nusantara Boarding School Padaherang, catatan/agenda pelaksanaan pendidikan karakter dan sumber referensi lainnya.

Teknik pengumpulan data merupakan langkah yang paling utama dalam penelitian, karena tujuan utama dari penelitian adalah mendapatkan data. Dalam penelitian kualitatif, pengumpulan data dilakukan pada natural setting (kondisi yang alamiah), sumber data primer, dan teknik pengumpulan data (Sugiyono, 2012, p. 308). Adapun teknik pengumpulan data pengembangan karakter peserta didik berbasis pendidikan agama Islam di SMA Ksatria Nusantara Boarding School Padaherang dilakukan dengan teknik observasi, wawancara, teknik dokumentasi dan triangulasi.

\section{Hasil Penelitian dan Pembahasan}

Pengembangan karakter peserta didik berbasis pendidikan agama Islam di SMA Ksatria Nusantara meliputi perencanaan, pelaksanaan dan hasil pengembangan karakter peserta didik serta beberapa temuan penelitian berdasarkan pelaksanaan penelitian di SMA Ksatria Nusantara.

\section{Perencanaan Pengembangan Karakter di SMA Ksatria Nusantara}

Perencanaan merupakan suatu proses yang tidak berakhir bila rencana tersebut telah ditetapkan, rencana harus diimplementasikan. Perencanaan menjadi pegangan setiap pemimpin dan pelaksana untuk dilaksanakan. Dengan demikian, melalui perencanaan dapat dipersatukan kesamaan pandangan, sikap dan tindak dalam pelaksanaan dilapangan (Al-Hamdani, 2017, p. 69). Berikut merupakan beberapa langkah-langkah yang dilakukan dalam perencanaan pengembangan karakter di SMA Ksatria Nusantara: Pertama, penyusunan kurikulum pendidikan. Kurikulum di SMA Ksatria mencakup visi, misi dan tujuan sekolah, muatan kurikulum sekolah yang diintegrasikan dengan kurikulum pesantren kemudian dikembangkan dalam Rencana Pelaksnaan Pembelajaran (RPP), budaya sekolah dan ekstra kulikuler.

Kedua, sosialisasi kepada peserta didik, kepala sekolah, kurikulum dan guru mata pelajaran. Tujuannya adalah menyampaikan tentang konsep pendidikan karakter di sekolah serta menyamakan persepsi tentang proses 
pengembangan dan implementasi nili karakter saat proses pembelajaran. Ketiga, membuat tata tertib dan peraturan yang disepakati bersama. SMA Ksatria Nusantara merupakan sekolah berbasis pesantren maka peraturan sekolah dipadukan dengan peraturan pesantren.

Berikut merupakan hasil wawancara [seluruh wawancara dengan pihak terkait dilaksanakan pada tanggal 13 September 2019] dengan kepala sekolah mengenai tahapan perencanaan pengembangan karakter di SMA Ksatria Nusantara:

Proses pengembangan karakter di SMA Ksatria Nusantara basic-nya pesantren. Pendidikan pesantren selain mempelajari kitab pendidikan karakter sudah mulai diterapkan dari awal, maka pengembangan karakter di SMA Ksatria Nusantara melanjutkan dari kurikulum pesantren. Misalnya pembiasaan bangun pagi setelah adanya SMA Ksatria Nusantara lebih di tekankan lagi, kemudian dibuatlah a $\underline{h} w \bar{a} l$ yaumiyah, penilaian 24 jam.

Lebih lanjut beliau menjelaskan bahwa ada rapor kepribadian peserta didik. Rapor kepribadian tersebut dibuat yang berisi tentang penilaian peserta didik selama 24 jam. Rapor ini diisi oleh waka kesiswaan bekerjasama dengan guru pamong, OSIS dan Organisasi Santri Intra Pesantren (OSIP). Rapor kepribadian dibuat berdasarkan keimanan, ketakwaan, akhlak mulia, kedisiplinan, keindahan, keamanan, ketertiban, kerja sama dan nilai yang mengandung kegiatan belajar mengajar di sekolah.

Proses perencanaan pengembangan karakter saat pembelajaran terlihat saat pembuatan silabus dan RPP yang disesuaikan dengan kompetensi inti saat proses pembelajaran berlangsung. Sebagaimana diungkapkan oleh Abdul Rojak, sebagai Waka Kurikulum:

Pelaksanaan pendidikan karakter bukan hanya pada saat pembelajaran berlangsung, tetapi di mulai sebelum pembelajaran dilaksanakan, yaitu dengan membuat rencana pembelajaran yang berbasis karakter. Selain itu, pendidikan karakter juga membutuhkan keteladanan dari guru untuk menunjang keberhasilannya. Sehingga dalam hal ini, guru harus menjadi contoh bagi peserta didik dalam bersikap, berbicara dan berpenampilan.

Pengembangan nilai-nilai karakter dalam penyusunan perencanaan pelaksanaan pembelajaran di SMA Ksatria Nusantara melalui silabus dan RPP sudah dilakukan dengan memasukkan nilai-nilai karakter tertentu sesuai konteks dan konten materi yang akan disampaikan pada peserta didik dalam kegiatan pembelajaran. Sebagai contoh nyata, dalam studi dokumentasi terlihat jelas bahwa terdapat nilai karakter yang dikembangkan diantaranya nilai religius, jujur, toleransi, disiplin, kerja keras, mandiri, demokratis, rasa ingin tahu, semangat kebangsaan, cinta tanah air, menghargai prestasi, bersahabat, cinta damai, gemar membaca, peduli lingkungan, peduli sosial dan tanggung jawab. Nilai-nilai yang ada dalam silabus tersebut selanjutnya dikembangkan 
dalam RPP dengan memasukkan nilai-nilai budaya dan karakter bangsa dalam indikator pencapaian kompetensi.

\section{Pelaksanaan Pengembangan Karakter di SMA Ksatria Nusantara}

Pelaksanaan adalah aktifitas atau usaha-usaha yang dilaksanakan untuk melaksanakan semua rencana dan kebijaksanaan yang telah dirumuskan dan ditetetapkan dengan dilengkapi segala kebutuhan, alat-alat yang diperlukan, siapa yang melaksanakan, di mana tempat pelaksanaannya mulai dan bagaimana cara yang harus dilaksanakan (Al-Qarni, 2018).

Pelaksanaan pengembangan karakter di SMA Ksatria Nusantara sesuai dengan perencanaannya yaitu dengan langkah: 1) penyusunan kurikulum yang mencakup visi, misi, dan tujuan sekolah, muatan kurikulum sekolah yang diintegrasikan dengan kurikulum pesantren; 2) sosialisasi kepala sekolah, waka kurikulum dan guru mata pelajaran tentang konsep pendidikan karakter; dan 3) membuat tata tertib dan peraturan sekolah yang disepakati bersama. Semuanya diimplementasikan melalui pembiasaan, pembelajaran dan keteladanan.

Pembiasaan merupakan salah satu metode pendidikan Islam yang sangat penting bagi pesrta didik, karena dengan pembiasaan inilah akhirnya suatu aktifitas akan menjadi milik peserta didik dikemudian hari (Djamarah \& Zain, 2002, pp. 71-72). Ciri khas metode pembiasaan adalah kegiatan yang berupa pengulangan berkali-kali dari suatu yang sama (Arief, 2002, p. 110).

Implementasi pengembangan karakter melalui pembiasaan di SMA Ksatria Nusantara seperti memulai dan mengakhiri kegiatan rangkaian sekolah dengan membaca do'a, membaca Alquran surat al-Wāqi'ah setiap hari Senin dan Kamis, diupayakan melaksanakan puasa sunah Senin dan Kamis dan program Jum'at berkah, yaitu belajar infak setiap hari Jum'at. Seluruh warga sekolah juga diminta untuk melaksanakan shalat dhuha pada saat istirahat pertama. Sebagaimana hasil wawancara dengan salah satu siswi SMA Ksatria Nusantara menyatakan bahwa:

Peserta didik SMA Ksatria Nusantara mengisi waktu istirahat sebagian diisi dengan ibadah, misalnya istirahat pertama diisi dengan melaksanakan sholat dhuha dan istirahat kedua diisi dengan melaksanakan sholat dhuhur berjamaah. Khusus hari senin dan kamis setelah sholat dhuha peserta didik membaca Alquran surat al-Wāqi'ah.

Implementasi pengembangan karakter melalui pembelajaran dicantumkan dalam rencana pelaksanaan pembelajaran (RPP) mulai dari tahapan pendahuluan, inti dan penutup yang dipilih agar peserta didik mempraktekan nilai-nilai karakter yang ditargetkan (Syarif, Hamzah, \& Mustofik, 2016, p. 34). Guru juga harus mampu menyesuaikan dengan kondisi dan situasi yang mungkin berbeda dengan apa yang telah direncanakan sebelumnya. Pelaksanaan tersebut menuntut guru untuk lebih kreatif dalam 
memfasilitasi peserta didik dengan cara mengajar agar mampu diterima peserta didik dengan baik khususnya dalam menanamkan nilai-nilai karakter. Lebih lanjut Milki Barokah menyatakan bahwa:

SMA Ksatria Nusantara yang berbasis pesantren secara otomatis peserta didiknya merupakan santri Pondok Pesantren Riyadussalikin, maka sekolah membatasi pemberian tugas atau pekerjaan rumah kepada peserta didik yaitu maksimal 2 tugas dalam setiap bulannya. Tujuannya agar peserta didik mampu menguasai pelajaran sekolah dan pesantren dengan seimbang. Hal tesebut menuntut guru untuk lebih kreatif dalam memberikan pelajaran kepada peserta didik dan mampu diterima dengan baik dengan menggunakan fasilitas yang ada.

Agar dapat merencanakan implementasi pendidikan karakter dalam pembelajaran, seorang guru memerlukan pelatihan. Berdasarkan hasil wawancara, guru SMA Ksatria Nusantara menyatakan pernah mengikuti pelatihan implementasi pendidikan karakter dalam mata pelajaran. Adapun jika ada guru yang tidak mengikuti pelatihan implementasi pendidikan karakter dalam mata pelajaran, maka guru tersebut melakukan komunikasi dengan guru sekolah lain yang mengampu mata pelajaran yang sama apabila mengalami kesulitan dalam merumuskan implementasi pandidikan karakter. Hal ini dikarenakan setiap mata pelajaran diampu oleh satu guru. Sebagaimana hasil wawancara dengan guru pelajaran prakarya bahwa:

Setiap guru dianjurkan mengikuti pelatihan implementasi pendidikan karakter dalam mata pelajaran yang kemudian akan diterapkan pada silabus dan RPP, akan tetapi jika ada guru yang tidak mengikuti atau belum paham maka guru tersebut melakukan komunikasi dengan guru sekolah lain yang mengampu mata pelajaran yang sama. Hal ini dikarenakan setiap mata pelajaran diampu oleh satu guru.

SMA Ksatria Nusantara selain mempunyai laporan hasil belajar siswa juga mempunyai laporan khusus tentang kepribadian siswa. Hal ini menunjukkan SMA Ksatria Nusantara mendidik peserta didik tentang normanorma melalui sistem score. Peserta didik yang tidak mentaati peraturan baik peraturan Pondok Pesantren Riyadussalikin maupun peraturan SMA Ksatria Nusantara, akan mendapat score. Peserta didik akan diberi peringatan dengan naik kelas bersyarat apabila score yang diperoleh sudah mencapai batas maksimal. Apabila peserta didik tidak berubah, maka peringatan selanjutnya peserta didik akan dikeluarkan dari sekolah. Penggunaan sistem score tersebut bertujuan untuk melatih peserta didik mengenai nilai disiplin dan tanggung jawab. Sesuai dengan pendapat Gunawan, bahwa salah satu tujuan pendidikan karakter di sekolah, yaitu untuk membantu peserta didik dalam memahami nilai-nilai perilaku manusia yang berhubungan lingkungan dan kebangsaan yang terwujud dalam pikiran, perasaan, sikap, perkataan dan perbuatan agar sesuai dengan norma-norma serta adat istiadat (Gunawan, 2012, p. 39).

Selain terdapat pada pembiasan dan pembelajaran, pelaksanaan pendidikan karakter di SMA Ksatria Nusantara, sebagaimana hasil wawancara 
dan hasil observasi, juga dilakukan melalui teladan guru. Keteladanan bukan hanya sekedar memberikan contoh dalam melakukan sesuatu, tetapi juga menyangkut berbagai hal yang dapat diteladani, termasuk kebiasaan-kebiasaan yang baik merupakan contoh bentuk keteladanan (Hidayatulloh, 2009, pp. 105-106). Proses keteladanan yang baik akan membuat peserta didik terbiasa dan mengikuti sikap baik dari pihak kepala sekolah, guru dan karyawan. Hal tersebut diungkapkan oleh kepala sekolah bahwa:

Pelaksanaan pengembangan karakter tidak hanya dalam pembelajaran yang lebih ditekankan adalah keteladanan dari guru, karena dengan keteladanan lebih berpengaruh kepada peserta didik. SMA Ksatria Nusantara meskipun sekolah berbasis pesantren, dalam penyeleksian guru tidak harus berlatar belakang kepesantrenan, yang diutamakan adalah linieritas. Meskipun begitu, semua guru dan staf sekolah ketika di sekolah harus mengikuti peraturan pesantren dan mampu memberikan keteladanan kepada setiap siswa.

Lebih lanjut siswa SMA Ksatria Nusantara menyatakan bahwa:

Dalam pelaksanaan pengembangan karakter di SMA Ksatria Nusantara dicontohkan oleh guru dan ustadz dari sekolah maupun pesantren, namun dalam sholat berjamaah terkadang ada guru yang tidak mengikuti.

Hasil penelitian tersebut sesuai dengan kajian teori yang didapat mengenai metode pembentukan karakter. Menurut Helmawati, keteladanan dalam pendidikan merupakan metode yang paling berpengaruh bagi anak didik. Oleh karena itu, ketika peserta didik berada di sekolah, guru tidak hanya mengajarkan pendidikan karakter melalui ilmu-ilmu tetapi juga melalui teladan dari guru tersebut (Helmawati, 2017, pp. 26-29).

\section{Hasil Pengembangan Karakter di SMA Ksatria Nusantara}

Lickona yang dikutip oleh Kholiq memaparkan hal-hal yang perlu diamati untuk mengetahui hasil dari pengembangan karakter, yaitu: 1) kemajuan karakter peserta didik dapat diamati lewat perilakunya di lingkungan sekolah; 2) efek karakter pada lingkungan luar sekolah; 3) kehidupan peserta didik setelah lulus dari sekolah (Kholiq, 2012). Dari pemaparan tersebut maka hasil pengembangan karakter dapat dilihat dari kemajuan karakter peserta didik lewat perilakunya baik di lingkungan sekolah maupun di lingkungan pesantren, hasilnya memang tak akan terlihat seketika. Sebagaimana yang diungkapkan oleh kepala sekolah, beliau menyatakan bahwa:

Hasil pendidikan karakter yang diberikan kepada siswa tidak bisa langsung terlihat dalam jangka pendek. Seperti pembiasaan bangun pagi yang merupakan pembiasaan dari pesantren, bagi siswa baru yang belum terbiasa bangun pagi.

Pernyataan ini sependapat dengan Fahlevi, bahwa karakter dimulai dari pola pikir yang kemudian diwujudkan dalam tindakan, bila dilakukan terus menerus maka akan menjadi kebiasaan. Karakter yang positif tidak akan muncul dengan sendirinya. Untuk dapat membentuknya, hal pertama yang 
harus dilakukan adalah mengubah pola pikir, tingkah laku dan kebiasaan menjadi positif (Fahlevi, 2016, p. 44).

Dari hasil penelitian melalui wawancara yang dilaksanakan pada tanggal 13 September 2018 dengan kepala sekolah, guru dan peserta didik yang ada di SMA Ksatria Nusantara, bahwa pengembangan karakter berbasis pendidikan agama Islam sudah dirasa cukup berhasil, karena visi misi dari sekolah ini sudah tercapai. Selain itu, kurikulum yang dilaksanakan di SMA Ksatria Nusantara merupakan salah satu program perbaikan sekolah yang dirasa kreatif dalam mengambangkan karakter, yaitu memadukan kurikulum pesantren dengan kurikulum bela negara. Tujuannya adalah ingin mencetak output yang lebih baik lagi agar pengembangan karakter di SMA Ksatria Nusantara dapat meningkat.

Selanjutnya hasil penelitian langsung yang diamati oleh peneliti dari pengembangan karakter peserta didik berbasis pendidikan agama Islam, yaitu pertama, karakter kuat. Peserta didik SMA Ksatria Nusantara dilatih untuk mempunyai karakter kuat. Karakter kuat di SMA Ksatria Nusantara tidak hanya identik dengan kuat fisik melainkan juga kuat psikis dan kuat kecerdasan. Ketiga karakter kuat tersebut tidak dapat dipisahkan. Implementasi kuat fisik, peserta didik diharuskan mengikuti senam pagi setiap hari dan taekwondo setiap hari Sabtu. Implementasi kuat psikis, peserta didik dilatih dengan olah jiwa melalui dzikir dan riyadhah. Kemudian implementasi kuat kecerdasan, peserta didik dilatih dengan talaran-talaran, baik talaran kitab maupun talaran Alquran. Sebagaimana hasil wawancara dengan kepala sekolah, sebagai berikut:

Kuat di sini identik dengan kuat fisik, kuat mental dan kuat ingatan. Ketiga itu tidak bisa dipisahkan, jadi fisiknya harus kuat, psikisnya harus kuat dan kecerdasannya juga harus kuat. Penerapan kuat fisik dengan melakukan senam pagi setiap hari, kuat psikisnya anak dilatih dengan olah jiwa melalui dzikir, kalau kuat kecerdasannya anak dilatih dengan tahfidz, baik tahfidz Alquran maupun kitab kuning.

Kedua, melatih kesabaran. Sabar dalam pengendalian diri, misalnya, sabar dalam menunggu jadwal izin pulang, tujuannya agar peserta didik tidak sering pulang dalam jangka waktu yang lama dan berdekatan. Selanjutnya peserta didik dilatih kesabaran dengan peraturan yang ada baik peraturan sekolah maupun peraturan pesantren, seperti tidak boleh membawa gadget, mengamalkan puasa senin kamis. Hal ini diutarakan oleh guru kepala sekolah, yaitu:

Peserta didik dilatih kesabaran. Misalkan sabar gak nih anak nunggu jadwal perpulangan sebulan sekali, sabar dengan peraturan yang ada seperti pake gadget dibatasin, dengan menjalankan puasa sunah.

Ketiga, menumbuhkan kejujuran. Adanya sistem score untuk mengetahui kejujuran peserta didik dapat terlihat. Salah satunya, setiap hari Selasa dan 
Jum'at selesai kegiatan apel pagi, peserta didik yang tidak melaksanakan puasa sunah Senin Kamis, atau tidak mengikuti sholat berjamaah, maka akan di berikan sanksi tanpa melihat absensi, tetapi dengan kejujuran masing-masing. Dibutuhkan kerja keras untuk menumbuhkan kejujuran pada peserta didik. Sebagaimana hasil wawancara dengan waka kurikulum, sebagai berikut:

Pemberian sanksi dilaksanakan setiap hari Selasa dan Jum'at selesai kegiatan apel. Meskipun adanya absensi setiap kegiatan, namun siswa yang melanggar peraturan sekolah maupun peraturan pesantren tidak boleh meninggalkan lapangan dengan kejujuran masing-masing. Dari pelaksanaan ini dapat mengetahui tingkat kejujuran siswa.

Keempat, disiplin. Peserta didik dilatih untuk berdisiplin dengan melakukan setiap kegiatan sesuai dengan ahwwäl al-yaumiyah. Paksaan dalam melakukan kegiatan pembiasaan-pembiasaan akan menumbuhkan kedisiplinan. Salah satu bentuk paksaan yaitu dengan adanya absensi. Hal ini diungkapkan oleh salah satu siswa SMA Ksatria Nusantara, sebagai berikut.

Dengan adanya sistem score, absensi 24 jam, dan ahwāl yaumiyah menuntut siswa untuk disipin. Awalnya terasa berat dan terpaksa, namun lama-kelamaan menjadi biasa dan terbiasa.

Kelima, memiliki rasa tanggung jawab. Setiap peserta didik diberikan jadwal baik jadwal kebersihan, jadwal keamanan dan jadwal pulang, tujuannya agar peserta didik memiliki rasa tanggung jawab. Tanggung jawab peserta didik dapat dillihat dari bagaimana melaksanakan tugas meskipun tanpa perintah. Namun, dari hasil observasi penulis melihat, masih ada sebagian yang tidak mempunyai tanggung jawab akan tugasnya.

Keenam, saling menghormati dan memiliki sopan santun. Lingkungan pendidikan 24 jam dapat melatih peserta didik untuk saling menghormati baik kepada rekan sesama peserta didik, guru, maupun ustadz. Terbukti, peserta didik tidak membedakan dalam menghormati kepada guru sekolah layaknya kepada ustadz di pesantren. Sebagaimana hasil wawancara dengan kepala sekolah, yaitu:

Perlakuan siswa kepada guru di sekolah dan kepada ustadz tidak dibedakan, meskipun sebagian guru di sekolah bukan termasuk dari bagian ustadz di pesantren. Sesama siswa ketika memanggil nama orang didahului dengan sebutan "mang" untuk laki-laki dan sebutan "teh" untuk perempuan.

Ketujuh, gemar membaca. Setiap peserta didik diharuskan membaca buku minimal satu buku dalam satu semester. Sepuluh menit sebelum pembelajaran dimulai, setiap peserta didik mempersentasikan hasil bacaannya secara bergilir setiap hari. sebagaimana diungkapkan oleh salah satu peserta didik sebagai berikut.

Sepuluh menit sebelum pembelajaran dimulai ada literasi. Hal ini dilakukan secara bergantian tiap hari per-siswa. Apabila buku bagiannya telah selesai dibaca, maka tuker dengan teman yang telah selesai membaca juga. 
Dalam pengembangan karakter ini, terdapat faktor pendukung dan penghambat dalam pengembangan karakter peserta didik berbasis pendidikan agama Islam. Di antara faktor pendukung terselenggaranya pengembangan karakter berbasis pendidikan agama Islam di SMA Ksatria Nusantara yaitu: 1) Memadukan dua kurikulum sekaligus yaitu kurikulum pesantren dengan kurikulum sekolah; 2) Mengintegrasikan dua manajemen sekaligus, yaitu adanya komunikasi dan kerjasama yang baik antara pengurus pesantren dan sekolah, sehingga pendidikan berjalan beriringan dan seimbang; 3) Adanya keteladanan baik dari pihak pesantren maupun dari pihak sekolah. Keteladanan merupakan metode yang paling ampuh dalam pengembangan karakter.

Sementara faktor penghambat pengembangan karakter peserta didik berbasis pendidikan agama Islam adalah: 1) Menyatukan dua kalender pendidikan yang berbeda. Hal ini dikarenakan pesantren mengacu kepada kalender bulan Hijriyah, sedangkan sekolah mengacu pada kalender bulan Masehi. Namun untuk saat ini, keberlangsungan proses pendidikan disesuaikan dengan kegiatan pesantren yang telah ada terlebih dahulu; 2) Fasilitas kurang lengkap, sehingga kegiatan pembelajaran kurang maksimal. Meskipun fasilitas bukanlah hal pokok dalam kegiatan pembelajaran, namun fasilitas dapat menunjang berlangsungnya kegiatan pembelajaran; 3) Ada sebagian masyarakat yang kurang mendukung. Hal ini membuat SMA Ksatria Nusantara berusaha menjadi lebih baik lagi.

\section{Kesimpulan}

Dari penelitian yang telah diuraikan di atas dengan judul "Pengembangan Karakter Peserta Didik berbasis Pendidikan Agama Islam.” Bedasarkan hasil penelitian dan analisis data yang terkumpul dapat ditarik kesimpulan, bahwa perencanaan pengembangan karakter berbasis pendidikan agama Islam di SMA Ksatria Nusantara melalui beberapa langkah, yaitu dengan cara penyusunan kurikulum yang mencakup visi, misi, serta muatan kurikulum sekolah yang diintegrasikan dengan kurikulum pesantren, kemudian dikembangkan dalam pembiasaan, budaya sekolah dan pembelajaran. Workshop yang diikuti oleh kepala sekolah, waka kurikulum dan guru mata pelajaran tentang implementasi pendidikan karakter dalam pembelajaran. Langkah selanjutnya yaitu pembuatan tata tertib dan peraturan sekolah yang disepakati berasama.

Pelaksanaan pengembangan karakter di SMA Ksatria Nusantara sesuai dengan perencanaannya yaitu dengan langkah sebagai berikut: 1) Penyusunan kurikulum yang mencakup visi, misi dan tujuan sekolah, muatan kurikulum sekolah yang diintegrasikan dengan kurikulum pesantren; 2) Sosialisasi kepala sekolah, waka kurikulum dan guru mata pelajaran tentang konsep pendidikan 
karakter; 3) Membuat tata tertib dan peraturan sekolah yang disepakati bersama, kemudian diimplementasikan melalui pembiasaan, pembelajaran dan keteladanan. Implementasi pengembangan karakter melalui pembiasaan seperti memulai dan mengakhiri kegiatan rangkaian sekolah dengan membaca do'a, membaca Alquran surat al-Wäqi'ah setiap hari Senin dan Kamis, melaksanakan shalat Dhuha. Implementasi pengembangan karakter melalui pembelajaran dicantumkan dalam rencana pelaksanaan pembelajaran (RPP) mulai dari tahapan pendahuluan, inti, dan penutup yang dipilih agar peserta mempraktekan nilai-nilai karakter yang ditargetkan. Hasil dari pengembangan karakter berbasis pendidikan agama Islam dapat dilihat dari kemajuan peserta didik lewat perilakunya baik di lingkungan sekolah maupun di lingkungan pesantren, walaupun hasilnya memang tak akan terlihat seketika. Dari hasil wawancara pada kepala sekolah, guru dan peserta didik yang ada di SMA Ksatria Nusantara, dapat disimpulkan bahwa pengembangan karakter berbasis pendidikan agama Islam dirasa cukup berhasil karena visi misi sudah tercapai.

\section{DAFTAR PUSTAKA}

Al-Hamdani, D. (2017). Konsep Dasar Pendidikan Bernuansa Islam. Bandung: Nuansa Cendekia.

Al-Qarni, M. U. (2018, September 11). ekhardhi.blogspot.com/2010/12/pelaksanaan. Retrieved from ekhardhi.blogspot.com: http://ekhardhi.blogspot.com/2010/12/pelaksanaan.html

Aqib, H. Z., \& Amrullah, A. (2017). Pedoman Pendidikan Budaya dan Karakter Bangsa. Yogyakarta: Penerbit Gava Medika.

Aqila, Z., \& Sujak. (2011). Panduan dan Aplikasi Pendidikan Karakter. Bandung: Yram Widya.

Arief, A. (2002). Pengantar Ilmu dan Metodologi Pendidikan Islam. Jakarta: Ciputat Press.

Arikunto, S. (2002). Prosedur Penelitian: Suatu Pendekatan Praktek. Jakarta: PT Rineka Cipta.

Djamarah, S. B., \& Zain, A. (2002). Strategi Belajar Mengajar. Jakarta: PT Rineka Cipta.

Fahlevi, D. (2016). Paradigma: Awal dan Kesuksesan. Jakarta: PT Gramedia Pustaka Utama.

Gunawan, H. (2012). Pendidikan Karakter: Konsep dan Implementasi. Bandung: Alfabeta.

Helmawati. (2017). Pendidikan Karakter Sehari-Hari. Bandung: PT Remaja Rosdakarya.

Hidayatulloh, M. F. (2009). Guru Sejati: Membangun Insan Berkarakter Kuat dan Cerdas. Surakarta: Yuma Pustaka. 
Idi, A. (2015). Etika Pendidikan. Jakarta: Raja Grafindo Persada.

Izzan, A., \& Saehudin. (2015). Tafsir Pendidikan: Konsep Pendidikan Berbasis AlQur'an. Bandung: Humaniora.

Kholiq, N. (2012, Maret 12). nuansa-pendikar.blogspot.com/2012/03/manajemenpelaksanaan-pendidikan. Retrieved from nuansa-pendikar.blogspot.com: http://nuansa-pendikar.blogspot.com/2012/03/manajemen-pelaksanaanpendidikan.html

LPP. (2014). Panduan Penyusunan Skripsi. Ciamis: IAID.

Ma'shumah, L. A. (2001). Pendidikan Kesadaran Beragama pada Anak dalam Paradigma Pendidikan Islam. Yogyakarta: Pustaka Pelajar.

Moleong, L. J. (2017). Metodologi Penelitian Kualitatif. Bandung: PT Remaja Rosdakarya.

Mujib, A., \& Mudzakkir, J. (2006). Ilmu Pendidikan Islam. Jakarta: Kencama Prenda Media.

Mushlih, A. (2018). Analisis Kebijakan PAUD: Mengungkap Isu-Isu Menarik Seputar $A U D$. Wonosobo: Penerbit Mangku Bumi.

Narwati, S. (2013). Pendidikan Karakter. Yogyakarta: Familia.

Sani, H. R. (2016). Pendidikan Karakter: Mengembangkan Karakter Anak yang Islami. Jakarta: PT Bumi Aksara.

Saondi, O., \& Suherman, A. (2015). Etika Profesi Keguruan. Bandung: PT Refika Aditama.

Sugiyono. (2012). Metode Penelitian Kualitatif. Bandung: Alfabeta.

Suyitno, I. (2012). Pengembangan Pendidikan Karakter dan Budaya Bangsa Berwawasan Kearifan Lokal. Jurnal Pendidikan Karakter, 1-13.

Syarif, M., Hamzah, \& Mustofik. (2016). Pelaksanaan Pendidikan Karakter dalam Pembelajaran PAI di SMK Hasanah Pekanbaru. Jurnal Al-Thariqah, 27-40.

Tolchah, M. (2015). Dinamika Pendidikan Pasca Orde Baru. Yogyakarta: LKiS. 
